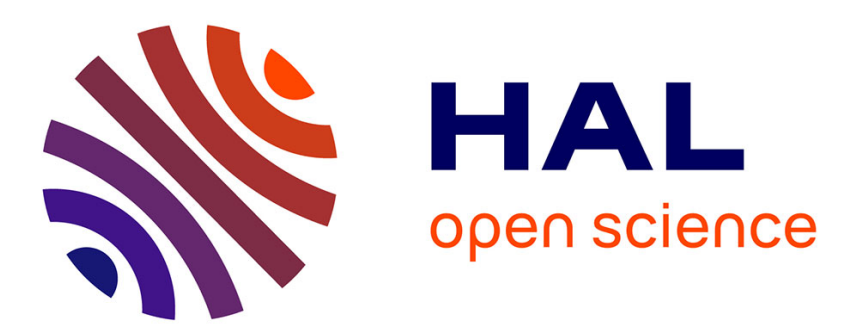

\title{
High-temperature oxidation and reduction of the inverse ceria/Cu(111) catalyst characterized by LEED, STM, nc-AFM and KPFM
}

\author{
Ali El Barraj, Baptiste Chatelain, Clemens Barth
}

\section{- To cite this version:}

Ali El Barraj, Baptiste Chatelain, Clemens Barth. High-temperature oxidation and reduction of the inverse ceria/Cu(111) catalyst characterized by LEED, STM, nc-AFM and KPFM. Journal of Physics: Condensed Matter, 2021, 10.1088/1361-648X/ac26f9 . hal-03399014

\author{
HAL Id: hal-03399014 \\ https://hal.science/hal-03399014
}

Submitted on 23 Oct 2021

HAL is a multi-disciplinary open access archive for the deposit and dissemination of scientific research documents, whether they are published or not. The documents may come from teaching and research institutions in France or abroad, or from public or private research centers.
L'archive ouverte pluridisciplinaire $\mathbf{H A L}$, est destinée au dépôt et à la diffusion de documents scientifiques de niveau recherche, publiés ou non, émanant des établissements d'enseignement et de recherche français ou étrangers, des laboratoires publics ou privés. 


\title{
High-temperature oxidation and reduction of the inverse ceria $/ \mathrm{Cu}(111)$ catalyst characterized by LEED, STM, nc-AFM and KPFM
}

\author{
Ali El Barraj, Baptiste Chatelain and Clemens Barth \\ Aix-Marseille Univ, CNRS, CINaM, Marseille, France \\ E-mail: barth@cinam.univ-mrs.fr
}

\begin{abstract}
The inverse catalyst 'cerium oxide (ceria) on copper' has attracted much interest in recent time because of its promising catalytic activity in the water-gas-shift reaction and the hydrogenation of $\mathrm{CO}_{2}$. For such reactions it is important to study the redox behaviour of this system, in particular with respect to the reduction by $\mathrm{H}_{2}$. Here, we investigate the high-temperature $\mathrm{O}_{2}$ oxidation and $\mathrm{H}_{2}$ reduction of ceria nanoparticles (NP) and a $\mathrm{Cu}(111)$ support by low energy electron diffraction (LEED), scanning tunnelling microscopy (STM), noncontact atomic force microscopy (nc-AFM) and Kelvin probe force microscopy (KPFM). After oxidation at $550^{\circ} \mathrm{C}$, the ceria NPs and the $\mathrm{Cu}(111)$ support are fully oxidized, with the copper oxide exhibiting a new oxide structure as verified by LEED and STM. We show that a high $\mathrm{H}_{2}$ dosage in the kilo Langmuir range is needed to entirely reduce the copper support at $550^{\circ} \mathrm{C}$. A work function (WF) difference of $\triangle \phi_{\mathrm{rCeria} / \mathrm{Cu}-\mathrm{Cu}} \approx-0.6 \mathrm{eV}$ between the ceria NPs and the metallic $\mathrm{Cu}(111)$ support is measured, with the $\mathrm{Cu}(111)$ surface showing no signatures of separated and confined surface regions composed by a $\mathrm{CuCe}$ alloy. After oxidation, the WF difference is close to zero $\left(\triangle \phi_{\mathrm{Ceria} / \mathrm{Cu}-\mathrm{Cu}} \approx-0.1 \ldots 0 \mathrm{eV}\right)$, which probably is due to a WF change of both, ceria and copper.
\end{abstract}

Keywords: Cerium oxide (ceria), $\mathrm{Cu}(111)$, oxidation, reduction, work function, low energy electron diffraction (LEED), scanning probe microscopy (SPM) 
Submitted to: J. Phys.: Condens. Matter

\section{Introduction}

Cerium oxide (ceria) is an important reducible oxide in heterogeneous catalysis [1, 2] due to its high oxygen storage capacity (OSC), which is based on the oxidation and reduction of cerium atoms and the accompanied filling and creation of oxygen vacancies, respectively [3]. Apart from other applications, ceria is used in the watergas-shift reaction $[4,5]$, the oxidation of hydrocarbons [5, 1] and in fuel cells $[6,7,8]$, with the most prominent application being the three-way-catalyst $[9,2]$. Insights into ceria's morphology, atomic structure and surface chemistry are obtained by surface science studies, which are mostly conducted under UHV conditions. In particular, model surfaces in the form of thick [10] and ultra-thin films [11, 12, 13, 14] have been studied in the recent past with standard surface science techniques.

Many studies deal with the conventional metal/ceria catalyst where ceria plays the role as a support for metal nanoparticles (NP) (e.g., PdNPs [15, 16], AuNPs [17], AgNPs [18]). However, the inverse catalyst composed of a metal surface supporting ceria (ceria/metal catalyst) can be more catalytically active [14]: for instance, the methanol production trough the hydrogenation of $\mathrm{CO}_{2}$ is higher on ceria/Cu compared to $\mathrm{Cu} /$ ceria $[19,20]$, which is also the case in the water-gas-shift (WGS) reaction [21].

When dealing with the inverse catalyst, the redox behaviour of ceria but also of the metal support has to be considered. For instance, metal surfaces like $\operatorname{Pt}(111)$ can form locally an alloy with cerium upon reduction [22]. The alloy then serves as a cerium reservoir that is used to form new ceria upon oxidation [23]. A similar mechanism can be observed on gold surfaces [24], where not an alloy but small NPs of cerium are formed from the released cerium [25]. Apart from forming an alloy, the metal surface can also form a surface oxide upon oxidation, as it is the case for ceria on $\mathrm{Cu}(111)$ [21]. When reducing the latter system by, e.g., $\mathrm{CO}$, the copper oxide transforms back into its metallic state [26]. From these perspectives it is evident that the metal modifies the reaction conditions during a redox cycle in dependence on its different states.

To study the role of a metal support that changes its state between being metallic and oxidized, the inverse ceria/ $\mathrm{Cu}(111)$ catalyst is an ideal model surface $[21,26]$. The ceria/ $\mathrm{Cu}(111)$ system has been extensively studied in the past [27], particularly by LEED [28, 29, 30, 31, 32, 33, 34, 35, 36, 37], RHEED [38, 15], LEEM [39, 40, 41], XPS $[29,30,42,26,43,44,33,34,45,35,20,46,36,47,37,15,48,41]$ and by STM $[30,32,26,49,33,34,45,35,46,36,47,37]$ as well as by density functional theory (DFT) $[21,26,49,50,19,51,41]$. Apart from the morphology, atomic structure and oxidation state of ceria, the reduction of ceria by $\mathrm{CO}[30,26], \mathrm{H}_{2}[19,41]$, atomic $\mathrm{H}$ [44], $\mathrm{Ce}[33,34,37]$ and the interaction with $\mathrm{CO}_{2}$ [47], $\mathrm{H}_{2} \mathrm{O}$ [44] and $\mathrm{SO}_{2}$ [43] were studied as well as some reactions like the water-gas-shift reaction [21], $\mathrm{CO}$ oxidation [26] and the hydrogenation of $\mathrm{CO}_{2}$ at high $\mathrm{H}_{2}$ and $\mathrm{CO}_{2}$ partial pressures [19, 20].

Whereas many studies deal with ceria films that almost entirely cover $\mathrm{Cu}(111)$, it is only a few that consider the inverse catalyst, mentioning either briefly copper oxide $[19,35,41]$ or focusing in some detail on the oxidation of the copper substrate in the presence of ceria [26]. With respect to the reduction by $\mathrm{H}_{2}$, two studies can be found in which very long $\mathrm{H}_{2}$ exposures of one day were applied, either with a very high $\mathrm{H}_{2}$ pressure in the mbar range and with the sample kept at room temperature [19] or with a pressure in the $10^{-6}$ mbar range and a sample temperature of $427^{\circ} \mathrm{C}$ [41]. 
In this work we investigate the high-temperature redox behaviour at $550{ }^{\circ} \mathrm{C}$ of the inverse catalyst ceria $/ \mathrm{Cu}(111)$, which is composed of nanometre high ceria nanoparticles $(\mathrm{NP})$ on $\mathrm{Cu}(111)$. Oxidation and reduction experiments are done with $\mathrm{O}_{2}$ and $\mathrm{H}_{2}$, respectively, both being in the $10^{-6}$ mbar range. We show that the system can be put either into its fully oxidized $\left(\mathrm{O}_{2}\right.$ oxidation $)$ or a mixed state $\left(\mathrm{H}_{2}\right.$ reduction), with copper entirely reduced and ceria being close to $\mathrm{CeO}_{2}$ stoichiometry. We report on a new copper oxide structure that is formed after the oxidation and comment on the work function (WF) difference between supported ceria and the copper support, which depends on the oxidation state of the system.

\section{Methods}

A detailed description of the sample preparation and material properties (absolute WF value for $\mathrm{Cu}(111)$, lattice constants of $\mathrm{Cu}$ and $\mathrm{CeO}_{2}$ ) as well as descriptions of our LEED, STM, nc-AFM and KPFM can be found in the supplementary information. Here, we summarize the most important details.

\subsection{Synthesis of ceria NPs}

The $\mathrm{Cu}(111)$ substrate is cleaned by repeated cycles of sputtering at $1.5 \mathrm{keV}$ and following UHV annealing at $550{ }^{\circ} \mathrm{C}$. Ceria NPs are grown by evaporation of Ce within 10 minutes onto the $\mathrm{Cu}(111)$ surface, which is kept at room temperature (RT). After the Ce deposition, the crystal is heated up in an UHV oven from RT to $550{ }^{\circ} \mathrm{C}$ in $3 \times 10^{-6}$ mbar $\mathrm{O}_{2}$ within 15 to 20 minutes. Afterwards, the sample remains for 10 minutes at $550{ }^{\circ} \mathrm{C}$ in $\mathrm{O}_{2}$ and is then cooled down to $300{ }^{\circ} \mathrm{C}$ within 15 minutes and still in $\mathrm{O}_{2}$. The cooling in $\mathrm{O}_{2}$ avoids a possible reduction of the ceria film as mentioned before for ceria/ $\mathrm{Pt}(111)$ films [52]. At $300{ }^{\circ} \mathrm{C}$, the sample is extracted from the oven and the $\mathrm{O}_{2}$ supply is stopped. The nominal thickness of the grown ceria is around $(5.7 \pm 0.5)$ mono-layers (ML).

\subsection{Oxidation/reduction experiments}

The sample is placed into the UHV oven at $300{ }^{\circ} \mathrm{C}$ and the temperature is increased such that it reaches $T_{\max }=550{ }^{\circ} \mathrm{C}$. After the annealing at $T_{\max }$, the temperature is decreased onto $300^{\circ} \mathrm{C}$ and the crystal is extracted from the oven. When annealing the sample only under UHV conditions, the pressure remains in the lower $10^{-10} \mathrm{mbar}$ pressure region. In the case of $\mathrm{O}_{2}$, the $\mathrm{O}_{2}$ exposure is started at $T_{\max }$ and is not stopped during the cooling until a temperature of $300{ }^{\circ} \mathrm{C}$ is reached, due to the reasons mentioned above. The same is done during $\mathrm{H}_{2}$ annealing if not otherwise specified (see Table 1 and below).

\subsection{SPM and LEED}

STM, frequency modulated nc-AFM and KPFM experiments as well as LEED experiments are performed in the same UHV chamber $\left(1 \times 10^{-10}\right.$ mbar base pressure $)$ [53] at room temperature. KPFM is used in the frequency modulation mode [54] and applied during the nc-AFM imaging in the constant $\triangle f$ mode. During the scanning of the surface, the electrostatic tip-surface interaction is minimized at each image point by the bias voltage, yielding the contact potential difference (CPD) between tip and 
Table 1. All redox steps conducted with the ceria/ $\mathrm{Cu}(111)$ sample in dependence on the redox cycle number (No.). A redox annealing step is done at $T_{\max }=550{ }^{\circ} \mathrm{C}$ during the time $\tau_{\text {Tmax }}$ (in $\min$ ) and at the pressure $p$ (in $10^{-6}$ mbar), which both yield the dosage $D_{\text {Tmax }}$ (in L). The total time and dosage, during which the sample is exposed to $\mathrm{O}_{2} / \mathrm{H}_{2}$ (annealing and cooling), is given by $\tau_{\text {tot }}$ and $D_{\text {tot }}$, respectively. In an oxidation/reduction step, the $\mathrm{O}_{2} / \mathrm{H}_{2}$ supply is stopped after the cooling of the sample down to $300^{\circ} \mathrm{C}$, despite for twoe reduction steps (no values for $\tau_{\text {tot }}$ and $D_{\text {tot }}$ ) where the $\mathrm{H}_{2}$ supply is stopped after the annealing at $T_{\max }$.

\begin{tabular}{|c|c|c|c|c|c|c|c|}
\hline No. & Step & $p$ & $\tau_{\text {Tmax }}$ & $\tau_{\text {tot }}$ & $D_{\operatorname{Tmax}}$ & $D_{\text {tot }}$ & Figure \\
\hline 0 & \multicolumn{7}{|c|}{10 min Ce deposition at RT } \\
\hline \multirow{6}{*}{1} & $\mathrm{Ox}$ & 3 & 10 & 35 & 1350 & 4730 & Fig. 2(a) \\
\hline & & & & & & & Fig. 3(a) \\
\hline & Red & $10^{-3}$ & 30 & 85 & UHV & UHV & Fig. S2 \\
\hline & Red & 1 & 30 & 60 & 1350 & 2700 & Fig. 2(b) \\
\hline & & & & & & & Fig. 3(b) \\
\hline & & & & & & & Fig. 4(a) \\
\hline \multirow{7}{*}{2} & $\mathrm{Ox}$ & 1 & 30 & 49 & 1350 & 2205 & Fig. S3 \\
\hline & & & & & & & Fig. 3(d) \\
\hline & & & & & & & Fig. 4(c) \\
\hline & Red & 1 & 30 & / & 1350 & / & Fig. S4(a)-(d) \\
\hline & & & & & & & Fig. S5(a) \\
\hline & Red & 10 & 30 & / & 13500 & / & Fig. S4(e),(f) \\
\hline & & & & & & & Fig. S5(b) \\
\hline \multirow{7}{*}{3} & $\mathrm{Ox}$ & 1 & 30 & 48 & 1350 & 2160 & Fig. 2(c) \\
\hline & & & & & & & Fig. 3(e) \\
\hline & & & & & & & Fig. 4(d) \\
\hline & Red & 20 & 60 & 79 & 54013 & 71117 & Fig. 2(d),(e) \\
\hline & & & & & & & Fig. 3(c) \\
\hline & & & & & & & Fig. 4(b), \\
\hline & & & & & & & Fig. S6 \\
\hline 0 & \multicolumn{7}{|c|}{ Clean $\mathrm{Cu}(111)$} \\
\hline l & $\mathrm{Ox}$ & 1 & 5 & 22 & 225 & 990 & Fig. 3(f),(g) \\
\hline & & & & & & & Fig. 4(e) \\
\hline & & & & & & & Fig. 5 \\
\hline & & & & & & & Fig. S7(c)-(e) \\
\hline
\end{tabular}

surface. An image of this voltage is simultaneously obtained with the topography nc-AFM image and called the CPD image.

\section{Results}

\subsection{KPFM experiments}

After the preparation of a clean $\mathrm{Cu}(111)$ substrate, a typical surface morphology with wide atomically flat terraces and ML high steps as well as a typical LEED pattern are obtained (see figure 1(a) and (b)). On such a substrate, the ceria nanoparticles (NPs) 

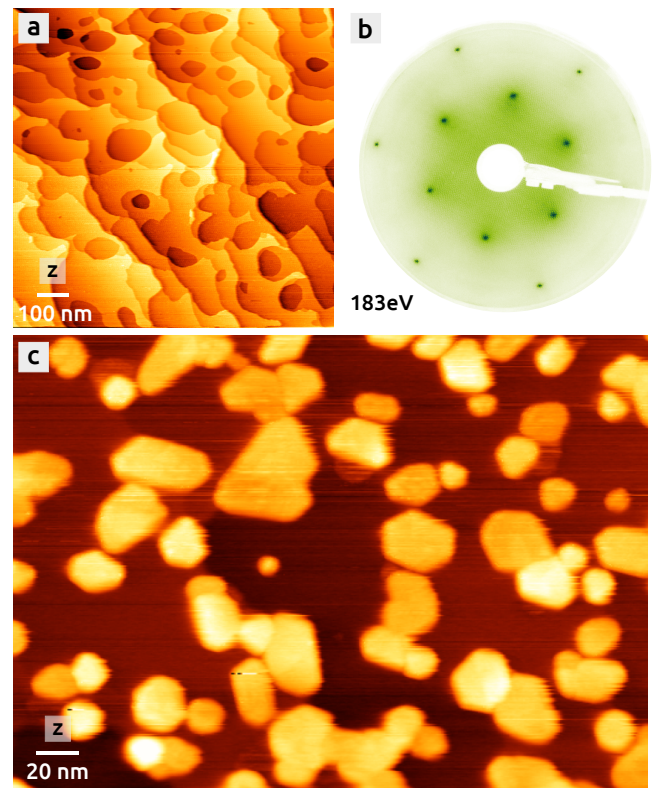

Figure 1. A typical large-scale STM topography image (a) and LEED pattern obtained at $183 \mathrm{eV}$ (b), after the preparation of a clean $\mathrm{Cu}(111)$ surface. (c) A nc-AFM topography image of the same surface after the growth of ceria NPs. STM: $I=0.18 \mathrm{nA}, \mathrm{U}_{\text {Bias }}=+2.32 \mathrm{~V}, v=3.0 \mathrm{~Hz}$. nc-AFM: $\triangle f=-11.8 \mathrm{~Hz}$, $f_{0}=74.0, v=0.5 \mathrm{~Hz}$.

are grown and treated in several redox steps, which are all summarized in table 1.

The nc-AFM topography image in figure 1 (c) shows the ceria NPs directly after the NP growth. Up to $40 \mathrm{~nm}$ large ceria NPs can be seen, covering about $40 \%$ of the substrate. Owing to their 3D shape, the NPs exhibit various truncated shapes, with the NPs' edges forming mostly angles of $60^{\circ}$ and $120^{\circ}$, which is due to their (111) epitaxy (see section 3.3). The mean NP height and density is around $4.2 \mathrm{~nm}$ and $1.0 \times 10^{11} \mathrm{NPs} / \mathrm{cm}^{2}$, respectively. Note that for all coverage and density values mentioned in this work, the error is around $\pm 8 \%$ and $\pm 3 \times 10^{10} \mathrm{NPs} / \mathrm{cm}^{2}$, respectively, because both parameters can change from surface site to surface site. Furthermore, due to the NP height distribution, the error of the mean height is around $\pm 0.5 \mathrm{~nm}$.

A typical CPD image of the as-prepared ceria NPs is shown in figure 2(a). The image is composed of four horizontally aligned bands of alternating contrasts ( 1 to 4 ), which are parallel to the horizontal fast scanning direction. The contrast changes correspond to voltages changes in the range of $0.1 \mathrm{~V}$. The abrupt changes of the contrast are due to changes of the tip's WF, which regularly appear during the imaging. As explained in detail in Ref. [55], the tip's WF can change upon re-arrangements of atoms or charges at the tip apex, which we believe is the reason here. When the tip's potential changes, the CPD between tip and surface changes in turn, producing bands as shown in the CPD image. Apart from the bands, a slight bright CPD contrast can be seen at the edges of the ceria NPs, which corresponds to a potential change of around $+0.1 \mathrm{~V}$ with respect to the support and the top facets of the ceria NPs. With respect to the ceria NPs and the support, almost no contrast differences is visible; 


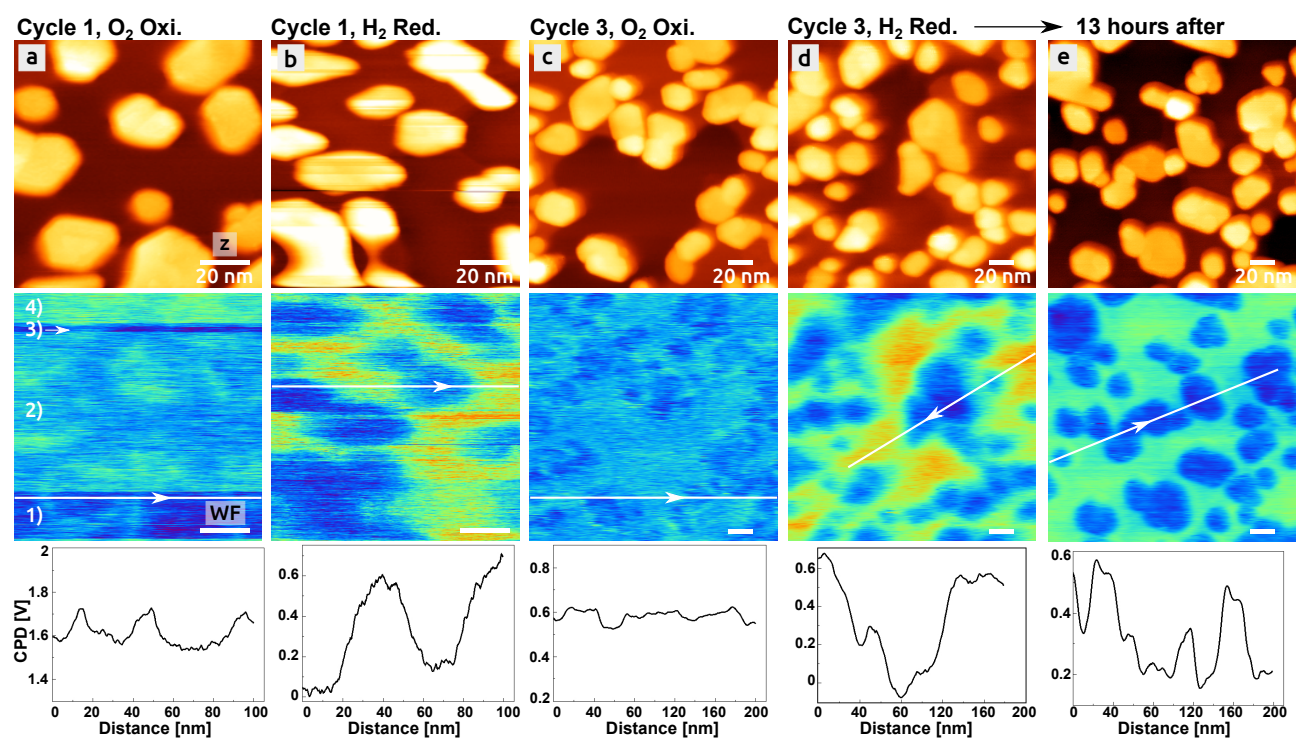

Figure 2. A selection of KPFM measurements obtained after successive redox steps listed in table 1 . The top row of images are topography nc-AFM images whereas the images below are CPD images. For clarity, tip changes in the CPD image (c) are removed. Underneath each CPD image, a representative profile shows the potential at the respective white line in the CPD image above. All profiles have the same CPD range of $0.7 \mathrm{~V}$. nc-AFM: $\triangle f=-13.7$ (a), -4.5 (b), $-22.0(\mathrm{c}),-17.0(\mathrm{~d})$ and $-35.0 \mathrm{~Hz}(\mathrm{e}), f_{0}=74.0(\mathrm{a}, \mathrm{b})$ and $76.5 \mathrm{kHz}(\mathrm{c}-\mathrm{e})$.

both regions seem to have more or less the same potential.

To check if the sample changes its morphology and/or surface potential upon $\mathrm{UHV}$ annealing only, the surface is annealed at $550^{\circ} \mathrm{C}$ during $30 \mathrm{~min}$ (see figure $\mathrm{S} 2$ in the supplmentary information). Despite the long annealing at the quite elevated temperature, no changes can be detected in the NP morphology (NP height: $4.3 \mathrm{~nm}$, NP coverage: $40 \%$, NP density: $\left.1.2 \times 10^{11} \mathrm{NPs} / \mathrm{cm}^{2}\right)$. The CPD image does not show any more the bright contrast at the edges of a NP but rather a decrease of the potential over the entire NP by $-0.15 \mathrm{~V}$ with respect to the support.

In contrast to the UHV annealing, the surface potential changes considerably, when annealing the sample during the same time and at the same temperature in $\mathrm{H}_{2}$ $\left(1 \times 10^{-6}\right.$ mbar, $\left.30 \mathrm{~min}, 1350 \mathrm{~L}, 550^{\circ} \mathrm{C}\right)$ as shown in figure $2(\mathrm{~b})$ : a clear dark contrast is visible at the ceria NPs, which corresponds to a potential decrease of up to $-0.6 \mathrm{~V}$ with respect to the copper support. There is no enhanced bright contrast at the edges of the NPs and the surface morphology is almost the same as after the film preparation (NP height: $4.3 \mathrm{~nm}$, NP coverage: $39 \%$, NP density: $0.8 \times 10^{11} \mathrm{NPs} / \mathrm{cm}^{2}$ ).

After this first $\mathrm{O}_{2} / \mathrm{H}_{2}$ cycle, the sample is annealed in $\mathrm{O}_{2}$ in cycle 2 with the same $\mathrm{O}_{2}$ dosage from above $\left(1 \times 10^{-6} \mathrm{mbar}, 30 \mathrm{~min}, 1350 \mathrm{~L}, 550^{\circ} \mathrm{C}\right)$. Similar phenomena as described for the as-prepared film can be observed (see figureS3(a) and (b) in the supplementary information): most importantly, the surface potential does not show any more the strong potential decrease at the NPs as in figure 2(b) but is rather homogeneous. Although a reduced potential can be seen at the ceria NPs after a following treatment in $\mathrm{H}_{2}$ with same parameters used before $\left(1 \times 10^{-6} \mathrm{mbar}, 30 \mathrm{~min}\right.$, $\left.1350 \mathrm{~L}, 550^{\circ} \mathrm{C}\right)$ the potential difference is considerably smaller $(-0.15 \mathrm{~V})$ than above 
(see figure $\mathrm{S} 4(\mathrm{a})$ and (b) in the supplementary information). Even a higher $\mathrm{H}_{2}$ dosage with a ten times higher dosage $\left(1 \times 10^{-5} \mathrm{mbar}, 30 \mathrm{~min}, 13500 \mathrm{~L}, 550^{\circ} \mathrm{C}\right)$ shows a less strong potential difference of max. $-0.4 \mathrm{~V}$ (see figure $\mathrm{S} 4(\mathrm{e})$ and (f) in the supplementary information).

Starting with an oxidation step in cycle 3, same observations can be made as in the two oxidation steps before (figure 2(c)): in the CPD image, a faint enhanced bright contrast at the edges of the NPs and merely a slightly reduced potential of $-0.1 \mathrm{~V}$ can be seen at the NPs. After a $\mathrm{H}_{2}$ annealing at $550{ }^{\circ} \mathrm{C}$, during which the sample is exposed to a very high $\mathrm{H}_{2}$ dosage of $54013 \mathrm{~L}\left(2 \times 10^{-5} \mathrm{mbar}, 60 \mathrm{~min}\right)$, a strong potential difference of $-0.6 \mathrm{~V}$ can be observed at the ceria NPs, which yet again have the same morphology as before (NP height: $4.3 \mathrm{~nm}$, NP coverage: $42 \%$, NP density: $1.0 \times 10^{11} \mathrm{NPs} / \mathrm{cm}^{2}$ ). Interestingly, by leaving the sample inside the UHV, the potential difference decreases by time such that after 13 hours, a maximum difference of only $-0.4 \mathrm{eV}$ can be observed (figure $2(\mathrm{e})$ ) whereas after two days the difference decreases even onto $-0.3 \mathrm{eV}$ (see figure $\mathrm{S} 6$ in the supplementary information).

\subsection{STM experiments}

In the following, STM experiments are presented to comment the oxidation state of the $\mathrm{Cu}(111)$ support. Figure 3(a)-(e) present several atomically resolved STM images obtained after some of the redox steps listed in table 1.

Figure 3(a) shows the copper support directly after the Ce deposition and the following $\mathrm{O}_{2}$ annealing in cycle 1: the surface is reconstructed and is composed of atomic features forming an ordered lattice with vertically oriented atomic rows. The unit cell represented by the red parallelogram has side lengths of $a=(8.2 \pm 0.5) \AA$ and $b=(26.5 \pm 0.5) \AA$, and an angle of $\alpha=(89 \pm 1)^{\circ}$ formed by $a$ and $b$. Because of the $\mathrm{O}_{2}$ annealing, a surface oxide has been created, which will be referred to as 'the new oxide structure' in the following (see Discussion Section). After the $\mathrm{H}_{2}$ annealing in cycle 1, a typical atomic contrast of a small hexagonal lattice can be seen (figure 3(b)), which dimension equals indeed the one of the $\mathrm{Cu}(111)$ lattice. The same clean $\mathrm{Cu}(111)$ surface is obtained after the $\mathrm{H}_{2}$ annealing in cycle 3 (figure $3(\mathrm{c})$ ). Overall, the oxidized copper surface gets entirely reduced by $\mathrm{H}_{2}$ to metallic $\mathrm{Cu}(111)$ in those two cases.

In cycle 2 , the oxidized surface shows again a reconstructed $\mathrm{Cu}(111)$ surface with a unit cell that is comparable to the one of the new oxide structure (see figure S3c,d in the supplementary information). However, occasionally we also observe a slightly different structure (figure $3(\mathrm{~d}))$ with a unit cell that is different in size $(a=(10.1 \pm 0.5) \AA$, $\left.b=(21.9 \pm 0.5) \AA, \alpha=\left(86 \pm 1^{\circ}\right)\right)$ compared to the new oxide structure. The size of this structure is comparable to the one of the " 44 " oxide structure previously observed by STM $[56,57,58,26,59]$. In cycle 3 , the new oxide structure is obtained again after the oxidation (figure $3(\mathrm{e})$ ), with a dimension of the unit cell being quite similar compared to the one of the new oxide structure $(a=(8.8 \pm 0.5) \AA, b=(26.2 \pm 0.5) \AA$, $\left.\alpha=(86 \pm 1)^{\circ}\right)$.

In general, after an oxidation of the sample, atomic sized defects are present on the copper oxide, depending on the surface site that is chosen for the imaging (see figureS3(c) in the supplementary information). As shown in figure 3(e), a defect disturbs the course of the atomic rows, which get displaced parallel to the row direction. This creates locally a different structure as shown by the orange parallelogram, which has a much smaller dimension with $a=(8.8 \pm 0.5) \AA$, $b=(17.2 \pm 0.5) \AA$ and $\alpha=(86 \pm 1)^{\circ}$. The size of this local structure is comparable with 

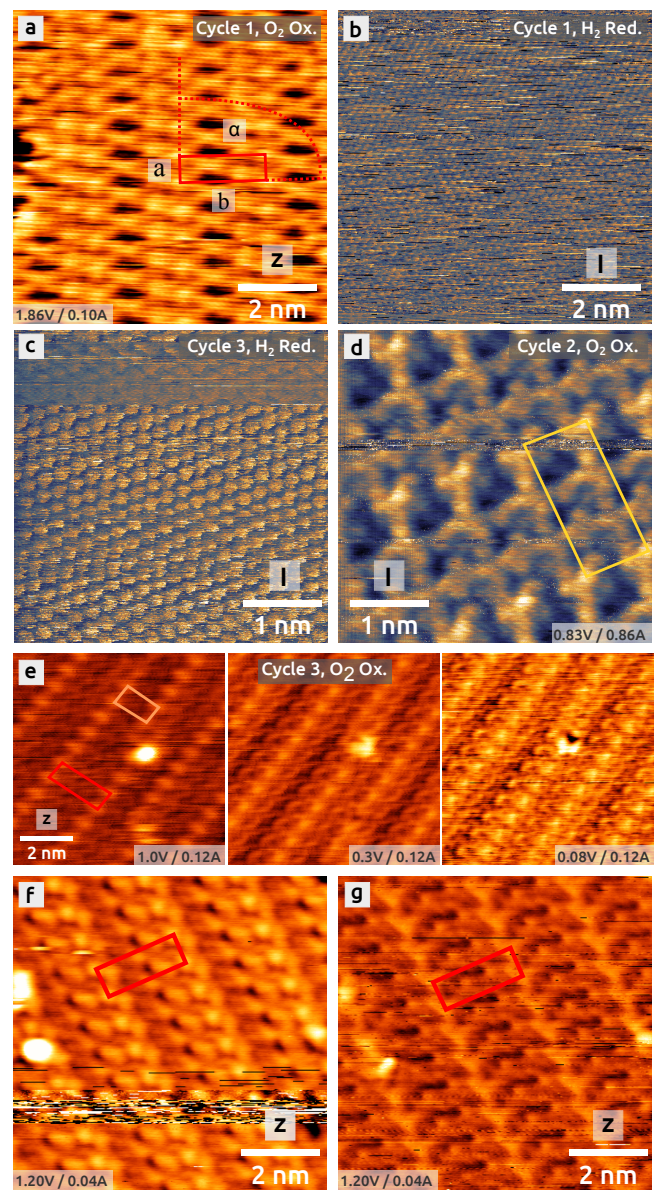

Figure 3. STM images obtained after a few selected redox steps listed in table 1 ((a)-(e)) and after an oxidation of only the $\mathrm{Cu}(111)$ surface without ceria ((f) and $(\mathrm{g}))$. The images show the lattice of the copper oxide ((a), (d), (e)-(g)) and the clean metallic $\mathrm{Cu}(111)$ surface $((\mathrm{b})$ and $(\mathrm{c}))$. Images $((\mathrm{a}),(\mathrm{e})-(\mathrm{g}))$ and $((\mathrm{b})-(\mathrm{d}))$ are topography and current images, respectively. The images (f) and (g) show the same surface region (same scanning parameters). The red, yellow and orange parallelograms show three cells found on the oxidized $\mathrm{Cu}(111)$ surface. STM: $I=0.10(\mathrm{a}), 0.91(\mathrm{~b}), 0.38(\mathrm{c}), 0.86(\mathrm{~d}), 0.12(\mathrm{e}), 0.04 \mathrm{nA}(\mathrm{f})$ and $(\mathrm{g}), \mathrm{U}_{\text {Bias }}=+1.86$ (a), +0.37 (b), +0.47 (c), +0.83 (d), $+1.0,+0.3,+0.08$ (e) and $+1.20 \mathrm{~V}$ (f) and $(\mathrm{g}), v=5.0(\mathrm{a})$ and (b), $9.8(\mathrm{c})$ and (e), $19.5(\mathrm{~d})$ and $6.5 \mathrm{~Hz}(\mathrm{f})$ and $(\mathrm{g})$.

the one of the "29" oxide structure previously observed by STM [56, 57, 60, 26, 61, 59]. In some rare cases, we also observe a high defect density and in turn a quite irregular atomic structure as shown in figure S3(d) of the supplementary information and similar to previous observations on oxidized $\mathrm{Cu}(111)$ [57].

To compare the atomic contrast observed on the oxidized ceria/ $\mathrm{Cu}(111)$ sample with the one of only the oxidized $\mathrm{Cu}(111)$ surface without ceria, a clean $\mathrm{Cu}(111)$ surface is prepared and oxidized at the same partial $\mathrm{O}_{2}$ pressure and temperature of $550^{\circ} \mathrm{C}\left(1 \times 10^{-6} \mathrm{mbar}, 5 \mathrm{~min}, 225 \mathrm{~L}\right.$ at $\left.T_{\max }\right)$. Two images obtained with same scanning parameters and at the same surface site are shown in figure $3(\mathrm{f})$ and $(\mathrm{g})$. They differ in their atomic contrast due to a tip change that appears in another image 
obtained between those two images (see figure S7d in the supplementary information). Independent on the contrast, the same dimension of the unit cell is observed with the side lengths $a=(9.3 \pm 0.5) \AA, b=(25.8 \pm 0.5) \AA$ and an angle $\alpha=(87 \pm 1)^{\circ}$. This structure, which we regularly observe on the oxidized $\mathrm{Cu}(111)$ surface, can be therefore assigned to the new oxide structure. Note that at the much lower oxidation temperature of $415^{\circ} \mathrm{C}$, we mostly observe the "29" oxide structure (figure $\mathrm{S} 7(\mathrm{~b})$ in the supplementary information).

Another regular observation is that the atomic contrast of the oxidized $\mathrm{Cu}(111)$ surface considerably changes when changing the bias voltage, e.g., from 1.0 to $0.08 \mathrm{~V}$, as shown by the three images in figure $3(\mathrm{e})$. A similar voltage dependence was also observed before when imaging the "29" and " 44 " oxide structure [61, 59]. Because of this and because we also regularly observe the above mentioned contrast changes upon tip changes, we do not compare the relative atomic contrast of the images. For this, a comparison with theory is needed to localize the atomic positions inside the unit cell as done before $[61,59]$.

\subsection{LEED experiments}

Selected LEED experiments are shown in figure 4, which supply information averaged over a large surface region about the atomic lattice of the ceria NPs and the copper substrate. LEED images obtained at 27 (left column) and $60 \mathrm{eV}$ (right column) show most important details.

After the reduction of the sample in cycle 1 and 3 (figure 4(a) and (b)), the LEED patterns show the typical diffraction spots for ceria (blue circles) and $\mathrm{Cu}(111)$ (red circles). Even if the contrast of the images is much enhanced, no other spots can be seen in between, also not at other electron energies in the range between 25 and $60 \mathrm{eV}$. The hexagonally arranged spots of ceria and $\mathrm{Cu}(111)$ is in agreement with the expected (111) orientation of $\mathrm{CeO}_{x}(111)$ and the $\mathrm{Cu}(111)$ support. The ratio of the reciprocal lattice vectors is around $r_{\text {Red }}=1.49 \pm 0.01$.

When oxidizing the sample, the typical diffraction spots for ceria (blue circles) and $\mathrm{Cu}(111)$ (red circles) can be found again, as exemplified with the sample oxidized in cycle 2 and 3 (figure $4(\mathrm{c})$ and (d)). The ratio of the reciprocal lattice vectors is a bit larger than before $\left(r_{\mathrm{Ox}}=1.51 \pm 0.02\right)$. A striking observation is, that there are many other, less bright LEED spots in between the ones originating from ceria and $\mathrm{Cu}(111)$. They can be best observed at relatively low electron energies between 15 and $30 \mathrm{eV}$, with $27 \mathrm{eV}$ yielding the the best contrast. Note that the same spots can still be seen after the reduction experiments in cycle 2 (see figure S5 in the supplementary information), where the potential difference between ceria and the support is relatively small (see KPFM experiments above).

To understand if the latter diffractions spots originate from ceria or $\mathrm{Cu}(111)$, a clean $\mathrm{Cu}(111)$ surface without ceria is oxidized under the same oxidation conditions $\left(1 \times 10^{-6}\right.$ mbar, $\left.5 \mathrm{~min}, 225 \mathrm{~L}, 550^{\circ} \mathrm{C}\right)$. The resulting LEED images are shown in figure $4(\mathrm{e})$ : at $60 \mathrm{eV}$, the typical hexagonally arranged $\mathrm{Cu}(111)$ spots are present. All the other spots of smaller intensity, which can be seen in particular at $27 \mathrm{eV}$, coincide almost perfectly with the additional spots of the oxidized ceria/Cu(111) sample (see, e.g., yellow ellipse). Figure 5 shows the LEED spots at $51 \mathrm{eV}$ in a high contrast: two types of rows can be seen (arrows), which corresponds to the atom rows visible in the STM images and which are rotated by $30^{\circ}$ to each other due to two domains that are present on the surface. At some places, we can estimate the location of the unit cell 


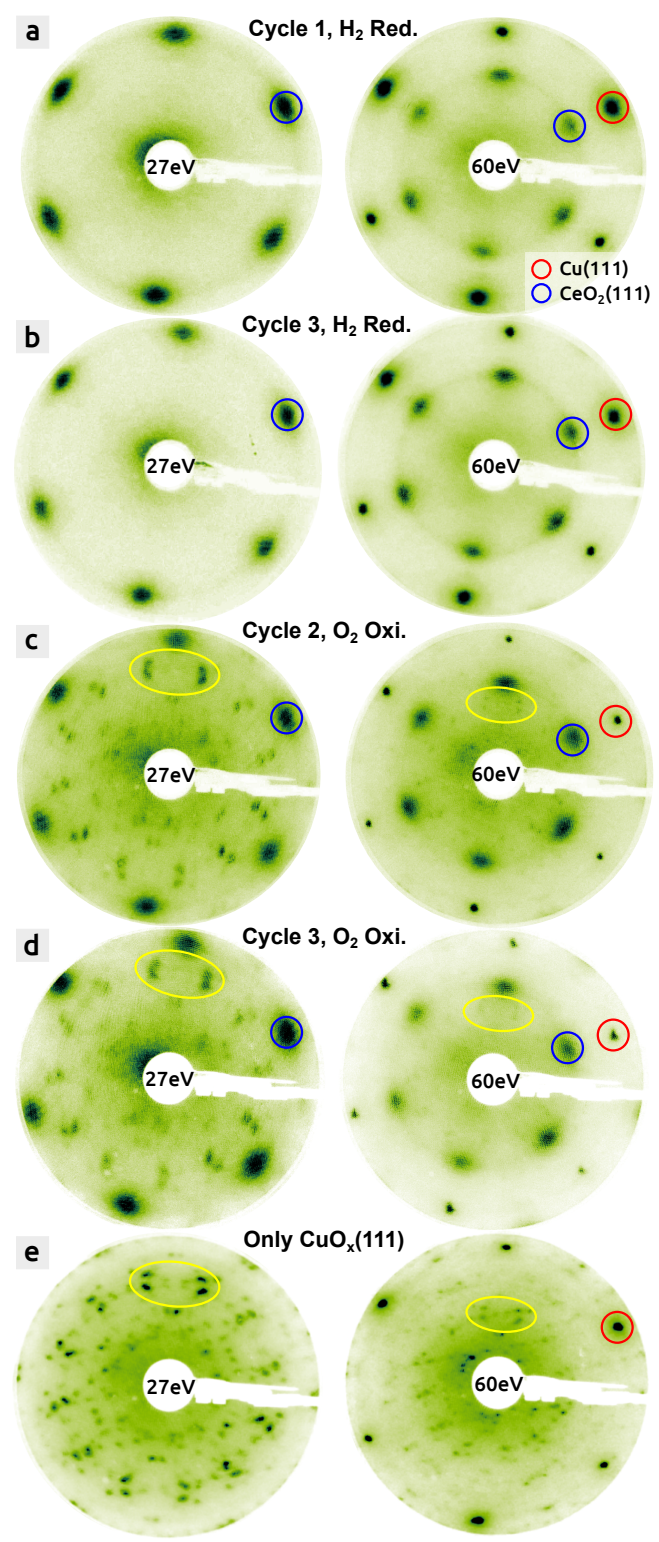

Figure 4. (a)-(d) LEED images obtained at 27 (left) and $60 \mathrm{eV}$ (right) on the ceria/ $\mathrm{Cu}(111)$ sample, after a few selected redox steps listed in table 1. (e) The LEED patterns of an oxidized $\mathrm{Cu}(111)$ surface without ceria. The blue and red circles show the typical diffraction spots for ceria and $\mathrm{Cu}(111)$, respectively, whereas the yellow ellipses are a guide to the eye to mark a few spots of the copper oxide that can be seen at 27 and $60 \mathrm{eV}$. 


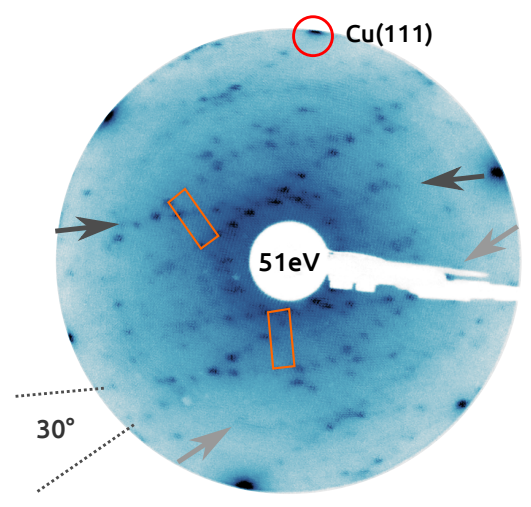

Figure 5. The LEED pattern of an oxidized $\mathrm{Cu}(111)$ surface without ceria obtained at $51 \mathrm{eV}$. The orange parallelograms mark the unit cell, which matches the one of the new oxide structure.

(orange parallelogram), which matches the one of the new oxide structure. Overall, we can assign the additional spots in figure 4(c) and (d) to the copper oxide rather than to the supported ceria.

\section{Discussion}

In the following, we discuss the oxidation and reduction of the ceria/ $\mathrm{Cu}(111)$ catalyst separately with help of figure 6 , which sketches the oxidation/reduction state of the sample in dependence on the eight redox steps.

\subsection{Oxidation}

The oxidation of the $\mathrm{Cu}(111)$ surface was extensively studied by LEED [62, 57], $\mu$ LEED/LEEM [63], XPS [64] and STM [56, 57, 60, 58, 61, 65, 64, 59], in particular in dependence on the temperature of the $\mathrm{O}_{2}$ annealing (from RT to $450^{\circ} \mathrm{C}$ ) and post-annealing $[60,57]$. The overall conclusion is that the surface reconstructs at temperatures starting at $\sim 300^{\circ} \mathrm{C}$, forming the "29" and " 44 " oxide structures [56]. It is therefore not astonishing that during an $\mathrm{O}_{2}$ annealing step at $550^{\circ} \mathrm{C}$ (figure 6 (a), (d) and (g)) the $\mathrm{Cu}(111)$ surface also oxidises in the presence of ceria islands or NPs that only partially cover the copper substrate, as indeed observed before [26, 35] and shown in this work.

However, in contrast to the latter work, we observe an oxide structure, which is much larger than the "29" oxide structure $\left(a_{29}=9.2 \AA, b_{29}=17.9 \AA\right)$ and which is different to the " 44 " oxide structure $\left(a_{44}=11.7 \AA, b_{44}=21.9 \AA\right)$ [56]. Our LEED data supports this new oxide structure: i) the diffraction spots do not match the spots of previously published LEED data of the "29" and " 44 " oxide structure $[62,57,63]$. ii) As shown in figure 5 , we can find the unit cell of the new oxide structure in its correct shape. Note that the unit cell is clearly different compared to the unit cells of the "29" and "44" oxide structure found by $\mu$ LEED [63].

A previously published work [26] reports on a new oxide structure, which is formed by supported ceria islands: the ceria islands enhance the dissociation of $\mathrm{O}_{2}$ and the oxide propagates from the islands. Unfortunately, no dimensional parameters of the 


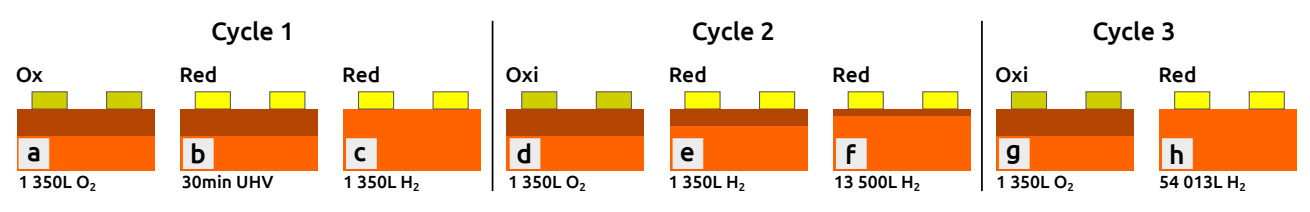

Figure 6. Sketches of the ceria/ $\mathrm{Cu}(111)$ oxidation state after all the eight redox steps conducted within 3 cycles at $550{ }^{\circ} \mathrm{C}$ (see table 1). The $\mathrm{O}_{2}$ and $\mathrm{H}_{2}$ dosage is mentioned at the bottom of the figure for each step. The copper support in its metallic state is drawn in an orange color whereas the surface oxide has a dark orange contrast, with the thickness illustrating the oxidation depth of the $\mathrm{Cu}(111)$ surface. Completely oxidized ceria is drawn in dark yellow whereas ceria is in yellow after a reduction step.

unit cell are mentioned in this work although the shape of the unit cell seems to be similar to the one which we regularly observe (compare with figure $3 \mathrm{~b}$ in Ref. $[26])$. Note that the annealing temperature used in the latter work $\left(5 \times 10^{-7}\right.$ torr, $\left.20 \mathrm{~min}, 600 \mathrm{~L}, 427^{\circ} \mathrm{C}\right)$ is much lower compared to our temperature $\left(1 \times 10^{-6} \mathrm{mbar}\right.$, $30 \mathrm{~min}, 1350 \mathrm{~L}, 550^{\circ} \mathrm{C}$ ). If our new oxide structure is the same as the one in Ref. [26], we anticipate that our $\triangle T=123^{\circ} \mathrm{C}$ higher temperature is the reason for the different observations made in Ref. [26] and here: we speculate that when oxidizing the system at $427^{\circ} \mathrm{C}$, not enough thermal energy is present for the new oxide creation and that ceria is needed to help in the way described in Ref. [26]. However, enough thermal energy is present at $550^{\circ} \mathrm{C}$ where ceria is not necessarily needed. In particular calculations have to reveal in future the detailed mechanisms involved in the oxide formation.

Comparing the values of the unit cell dimension, which we obtain from several atomically resolved STM images, the values deviate a bit from each other. The reason is that our STM/AFM works at RT where in particular the drift of the $\mathrm{x}, \mathrm{y}, \mathrm{z}$ scanner deforms the lattice. The drift varies from time to time so that slightly different values for the unit cell are obtained. Considering the values from above, we assume that the unit cell has a dimension given by $a=(9 \pm 1) \AA, b=(26 \pm 1) \AA$ and $\alpha=(88 \pm 2)^{\circ}$. In comparison to the " 44 " structure $\left(a_{44}=11.7 \AA, b_{44}=21.9 \AA\right)$, our new structure is thinner and longer. To find the exact positions of all atoms inside the unit cell, a comparison between STM and density function theory (DFT) like in Refs. [58, 61, 59] has to be done in future.

With respect to the ceria, we could not obtain the atomic resolution on the NP top facets, which is probably due to the high bias voltage that has to be used for a stable imaging $\left(U_{\text {Bias }}>3 \mathrm{~V}\right)$. The only information about the atomic lattice comes from LEED, which shows that the ceria NPs grow in their preferred (111) epitaxy. LEED supplies a value of $r_{\mathrm{Ox}}=1.51 \pm 0.02$ for the ratio of the reciprocal lattice vectors between ceria and $\mathrm{Cu}(111)$, being comparable with the previously found value of $1.5[28,31,32]$. With the lattice constant of $a_{\mathrm{Cu}, \mathrm{lit}, \exp }=(3.61 \pm 0.01) \AA$ for $\mathrm{Cu}$ (see table $\mathrm{S} 1$ in the supplementary information), we obtain a lattice constant of $a_{\mathrm{CeO} 2 \exp }=(5.45 \pm 0.09) \AA$, which is in good agreement with the experimental value of $a_{\mathrm{CeO} 2 \text {,lit,exp }}=(5.41 \pm 0.01) \AA$ obtained by X-ray scattering (see table S2 in the supplementary information). Overall, the nanometre thick ceria NPs in their fully oxidized state are not strained by the support and form an ordered oxide. The lattice of the oxide is commensurate and aligned with the principal crystallographic axes of the substrate as observed before for thinner ceria islands [31]. 
With respect to the ceria oxidation state, we can assume that the ceria NPs are made from stoichiometric $\mathrm{CeO}_{2}$, as this was previously measured by XPS on similar thick ceria films (5-6 ML: [31, 33], $12 \mathrm{ML}$ : [30]). In the latter work, samples were oxidized under similar oxidation conditions. Note that any possible contamination like $\mathrm{OH}$ or carbon species are removed by the oxygen annealing [66, 23], so that the ceria surface is also free from contamination.

It is surprising that no strong CPD difference between the ceria NPs and $\mathrm{Cu}(111)$ can be seen, after an oxidation step is done. In some cases, we observe no difference at all, in other cases we observe a slight reduction of $-0.1 \mathrm{~V}$ above the ceria NPs. The reason for this remains unknown so far. The bright contrast at the edges of the ceria NPs can be assigned to a more negative potential at the edges, probably produced by low coordinated negative atomic species like unscreened $\mathrm{O}$ ions as observed before on thick ceria films [67] and similar ionic surfaces like $\mathrm{CaF}_{2}(111)$ [68].

\subsection{Reduction}

After a sufficiently strong $\mathrm{H}_{2}$ reduction in the kilo Langmuir range at $550^{\circ} \mathrm{C}$, the copper substrate gets entirely reduced to metallic $\mathrm{Cu}(111)$ in cycle 1 and 3 (figure 6(c) and $(\mathrm{h})$ ), as it is evident from our STM and LEED data. The $\mathrm{H}_{2}$ dosage may vary at $550{ }^{\circ} \mathrm{C}$ : as observed in cycle 3 , a high dosage of $54000 \mathrm{~L}$ is needed to entirely reduce the copper oxide whereas the dosage in cycle 1 is only $1350 \mathrm{~L}$ high. The latter could not be reproduced in cycle 2, after which a $\mathrm{H}_{2}$ anneal with $1350 \mathrm{~L}$ and even $13500 \mathrm{~L}$ of $\mathrm{H}_{2}$ (figure $6(\mathrm{e})$ and (f)) leads to a potential difference of only $-0.4 \mathrm{~V}$ and to a LEED pattern with the additional spots of the oxide still included.

Table 1 shows that the oxidation time is 10 minutes long in cycle 1 whereas the one in cycle 2 is 30 minutes long, however, with a three times smaller $\mathrm{O}_{2}$ pressure compared to cycle 1 . We speculate that due to the longer oxidation time in cycle 2 , deeper subsurface layers of the copper support get oxidized than in cycle 1. As a consequence, the $\mathrm{H}_{2}$ dosage has to be higher in cycle 2 than in cycle 1 , as indeed shown by cycle 3 (exact same oxidation conditions as in cycle 2). This means that only a part of the oxide could be reduced upon the two $\mathrm{H}_{2}$ dosages in cycle 2 (figure 6(e) and (f)). Note that the $\mathrm{O}_{2}$ partial pressure values and related dosage values used in the work here are more elevated with respect to the 'standard pressure' of $5 \times 10^{-5} \mathrm{mbar}$ used in literature so that an oxidation of sub-surface regions is reasonable in our case.

Overall, $\mathrm{H}_{2}$ can be used as an reducing agent for an oxidized $\mathrm{Cu}(111)$ surface similar to CO $[21,26]$. Our work shows that due to the high temperature of $550{ }^{\circ} \mathrm{C}$ the reduction is much faster compared to a $\mathrm{H}_{2}$ reduction at $\mathrm{RT}$, at which a very high pressure of 1.5 torr during 26 hours is obviously needed [19].

With respect to the ceria NPs, we observe the perfect LEED pattern of the ceria (111) epitaxy and the metallic $\mathrm{Cu}(111)$ surface after a complete $\mathrm{H}_{2}$ reduction. The slightly smaller value for the ratio of the reciprocal lattice vectors between ceria and $\mathrm{Cu}(111)\left(r_{\text {Red }}=1.49 \pm 0.01\right)$ yields a slightly smaller lattice constant of $(5.38 \pm 0.05) \AA$ compared to the experimental value of $a_{\mathrm{CeO} 2, \mathrm{lit}, \exp }=(5.41 \pm 0.01) \AA$ (see table S2 in the supplementary information). This $\sim 0.6 \%$ small lattice contraction points to a possible lattice strain that is build up during the reduction, which has to be studied in more detail by future experiments.

There are no additional spots that appear in the LEED images in the energy range between 25 and $60 \mathrm{eV}$. This is quite surprising in view of the high temperature of $550{ }^{\circ} \mathrm{C}$ and the high $\mathrm{H}_{2}$ dosage as well as in view of previous LEED observations 
$[33,34,37]$ : the latter show that upon reduction by additional deposited Ce on 23 ML high ceria islands, which cover $50 \%$ of the $\mathrm{Cu}(111)$ surface, the atomic structure changes due to a loss of oxygen and the related reduction of $\mathrm{Ce}^{4+}$ to $\mathrm{Ce}^{3+}$ [37]. This considerably changes the LEED pattern starting with the $\iota-\mathrm{Ce}_{7} \mathrm{O}_{12} \mathrm{R} 19^{\circ}$ phase $\left(\mathrm{CeO}_{1.71}\right)$ and ending with the entirely reduced $\mathrm{Ce}_{2} \mathrm{O}_{3}$ phase $\left(\mathrm{CeO}_{1.5}\right)$. The same $\iota-\mathrm{Ce}_{7} \mathrm{O}_{12} \mathrm{R} 19^{\circ}$ phase is also the first phase that appears on $250 \mathrm{~nm}$ thick ceria films upon reduction [69]. All the latter LEED data let assume that the reduction of the ceria NPs in our work cannot be so high, eventually well below $50 \%$. Indeed, XPS shows that the efficiency of the $\mathrm{H}_{2}$ reduction is quite low: when annealing the sample at $427^{\circ} \mathrm{C}$ in $1.5 \times 10^{-6}$ mbar $\mathrm{H}_{2}$, about 20 hours are needed to obtain a $24 \%$ large reduction [41]. A very recent micro X-Ray absorption spectroscopy ( $\mu$ XAS-PEEM) study shows that the degree of reduction remains low $\left(\mathrm{CeO}_{\sim 1.9}\right)$ if a stoichiometric $\mathrm{CeO}_{2}(111)$ film is reduced by annealing at $550{ }^{\circ} \mathrm{C}$ during a dosage of $26000 \mathrm{~L}$ of $\mathrm{H}_{2}$ [70]. We therefore anticipate, that the degree of reduction is less than $20 \%$.

When the copper oxide is entirely reduced, we measure a potential difference of up to $-0.6 \mathrm{~V}$ between the ceria NPs and $\mathrm{Cu}(111)$. Because the contact potential difference $(\mathrm{CPD})$ between the sample and tip is determined by the WFs of both, $\mathrm{CPD}=\left(\phi_{\text {sample }}\right.$ $\left.\phi_{\text {tip }}\right) / e$ ), the potential difference between $\mathrm{Cu}(111)$ and ceria on $\mathrm{Cu}(111)$ is related to the WF difference at these surface sites: $\mathrm{CPD}_{\mathrm{rCeria} / \mathrm{Cu}}-\mathrm{CPD}_{\mathrm{Cu}}=\left(\phi_{\mathrm{rCeria} / \mathrm{Cu}}{ }^{-}\right.$ $\left.\phi_{\mathrm{Cu}}\right) / e=\triangle \phi_{\mathrm{rCeria} / \mathrm{Cu}-\mathrm{Cu}} / e$. Note that WF differences measured by KPFM can deviate from the true value due to the long-range electrostatic tip-surface interaction and the related tip-surface convolution effect: in the case of a blunt tip, the CPD includes also contributions from the $\mathrm{Cu}(111)$ surface if the tip is placed directly above a ceria NP. As a result, the contrast is blurred at the edges and a smaller value for $\triangle \phi$ is measured. Although the CPD well saturates in the middle of the up to $40 \mathrm{~nm}$ large ceria NPs (see figure 2(b), (d) and (e)) we nevertheless assume that the measured WF difference describes a lower limit.

With the WF difference of $\triangle \phi_{\mathrm{rCeria} / \mathrm{Cu}-\mathrm{Cu}} \approx-0.6 \mathrm{eV}$ between the ceria NPs and the clean $\mathrm{Cu}(111)$ surface (see figure 7 (a)), and with the absolute WF of $\phi_{\mathrm{Cu}(111)}=(4.90 \pm 0.02) \mathrm{eV}$ for $\mathrm{Cu}(111)$, the absolute $\mathrm{WF}$ of ceria $/ \mathrm{Cu}(111)$ is around $\phi_{\mathrm{rCeria} / \mathrm{Cu}} \approx 4.3 \mathrm{eV}$. Interestingly, the same WF reduction of $\triangle \phi_{\mathrm{rCeria} / \mathrm{Pt}-\mathrm{Pt}} \approx-0.6 \mathrm{eV}$ could be observed after reduction of ceria films on the $\mathrm{Pt}(111)$ surface [23], which has a considerably high WF $\left(\phi_{\operatorname{Pt}(111)}=(5.90 \pm 0.02) \mathrm{eV}\right)$, lifting therefore the WF of ceria onto $\phi_{\mathrm{rCeria} / \mathrm{Pt}} \approx 5.3 \mathrm{eV}$. This comparison clearly shows that $\mathrm{KPFM}$ is not measuring the WF of the ceria NPs alone but rather the WF of the metal underneath, under the influence of the ceria film. Interestingly, the WF difference decreases on a time scale of days when the sample is left in the UHV. As KPFM has shown to be very sensitive on adsorbed species on surfaces [71], we strongly anticipate that the sample gets contaminated by species from the residual gas of the UHV. Such contamination was observed also on PdNPs [72] and we suspect that it is in particular the reactive $\mathrm{Cu}(111)$ surface that reacts with the residual gas.

A very important difference with respect to the ceria/Pt(111) case is that the CPD contrast of the support is always homogeneous and constant, in particular after a complete $\mathrm{H}_{2}$ reduction. Therefore, we can assume that there is no local alloying effect between $\mathrm{Cu}$ and $\mathrm{Ce}$ such that destinctive regions of pure $\mathrm{Cu}(111)$ and regions of the alloy are created as in the case of ceria/Pt(111) [23]. A strong support comes from the morphology of the ceria NPs, where neither the coverage nor the height of the NPs noticeable changes upon a redox step unlike on ceria/Pt(111) [23]. In other words, no large amount of Ce is liberated during the reduction to form an alloy with 


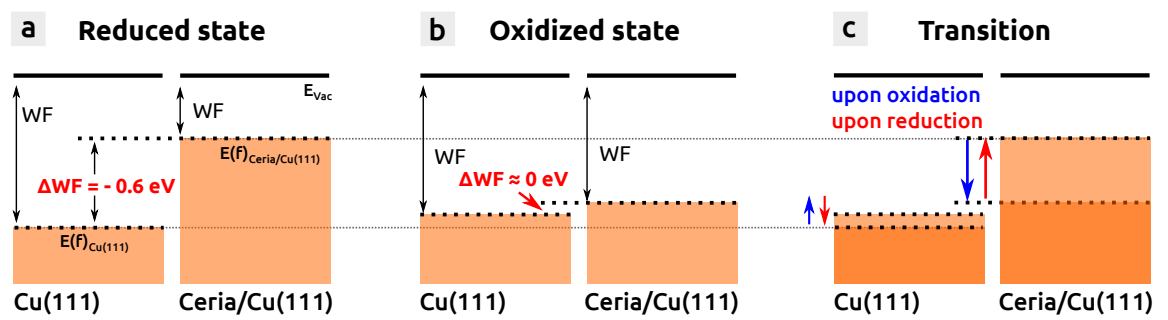

Figure 7. The $\mathrm{WF}$ state of ceria/Cu(111) and $\mathrm{Cu}(111)$ in the energy level diagram after reduction (a) and oxidation (b). Image (c) shows a possible trend of the WF change during oxidation and reduction. The Fermi and vacuum levels are denoted by $\mathrm{E}(\mathrm{f})$ and $\mathrm{E}_{\mathrm{Vac}}$.

$\mathrm{Cu}$. Note that we also always observe the perfect LEED spots of ceria and $\mathrm{Cu}(111)$ but no other spots and that we always observe the perfect $\mathrm{Cu}(111)$ lattice in STM.

In comparison, the fully oxidized ceria/ $\mathrm{Cu}(111)$ system has a WF difference close to zero $\left(\triangle \phi_{\mathrm{Ceria} / \mathrm{Cu}-\mathrm{Cu}} \approx-0.1 \ldots 0 \mathrm{eV}\right)$ (figure $\left.7(\mathrm{~b})\right)$. The question is, if one of the sites or both change their WF upon oxidation or reduction. A DFT calculation shows that the WF of stoichiometric $\mathrm{Cu}_{2} \mathrm{O}(111)$ is almost the same as the one of $\mathrm{Cu}(111)$ [73] (5.09 $\mathrm{eV}$ for $\mathrm{Cu}(111)$ versus $5.03 \mathrm{eV}$ for $\left.\mathrm{Cu}_{2} \mathrm{O}(111)\right)$. This means that upon reduction it is the ceria NPs on $\mathrm{Cu}(111)$, which decrease their WF by $-0.6 \mathrm{eV}$ (figure $7(\mathrm{c})$ ). Partial support comes from the unsuccessful $\mathrm{H}_{2}$ reduction experiments in cycle 2 (see figure $\mathrm{S} 4$ in the supplementary information): the copper oxide is still present but the WF difference between the ceria NPs and the copper support has decreased by $-0.4 \mathrm{eV}$, pointing to a contribution of only the Ceria $/ \mathrm{Cu}(111) \mathrm{WF}$. We speculate that when the copper support gets finally reduced by a following $\mathrm{H}_{2}$ reduction such as in cycle 3 , the WF difference decreases furthermore onto $-0.6 \mathrm{eV}$ because the copper support is then in its metallic $\mathrm{Cu}(111)$ state slightly increasing its WF (figure 7(c)). At this point, we clearly stress that our hypothesis has to be further investigated in future. We believe that in particular calculations such as in Ref. [59] have to be accomplished with respect to the WF of the new oxide structure because our new oxide structure differs considerably with respect to the one used in Ref. [73].

\section{Conclusion}

With help of our results obtained by LEED, STM, nc-AFM and KPFM, we comment on the redox behaviour of the inverse catalyst ceria/ $\mathrm{Cu}(111)$. With the temperature increasing from RT to $550^{\circ} \mathrm{C}$ and due to the relative high $\mathrm{O}_{2}$ partial pressure of $10^{-6}$ mbar, up to $4 \mathrm{~nm}$ high ceria NPs are created on $\mathrm{Cu}(111)$, which cover about $40 \%$ of the copper surface. The oxidation state of this system can be changed at will from a fully oxidized to a partially reduced state:

Upon oxidation with $\mathrm{O}_{2}$ and with the sample at $550^{\circ} \mathrm{C}$, the ceria $\mathrm{NPs}$ and $\mathrm{Cu}(111)$ support get both oxidized as shown by STM with atomic resolution. We find a new copper oxide structure with a unit cell $\left(a=(9 \pm 1) \AA, b=(26 \pm 1) \AA, \alpha=(88 \pm 2)^{\circ}\right)$, which is thinner and longer than the known " 44 " oxide structure. We observe the same structure also on only $\mathrm{Cu}(111)$ without ceria and assume that it is in particular the high temperature of $550^{\circ} \mathrm{C}$, which is responsible for the creation of this new oxide structure. 
An entire reduction of the oxidized copper substrate with $\mathrm{H}_{2}$ in the $10^{-6} \mathrm{mbar}$ range requires a high temperature of $550^{\circ} \mathrm{C}$ and high $\mathrm{H}_{2}$ dosage values in the range between 1 and some $10 \mathrm{~s}$ of $\mathrm{kL}$, depending on the thickness of the previously created copper oxide. Afterwards, the hexagonal lattice of the $\mathrm{Cu}(111)$ surface can be seen by STM. Because no LEED spots can be observed that can be assigned to a possible strong reduction of the ceria NPs we estimate that a reduction of the ceria NP is below $20 \%$.

After a complete $\mathrm{H}_{2}$ reduction, we measure a lower limit of $\triangle \phi_{\mathrm{rCeria} / \mathrm{Cu}-\mathrm{Cu}} \approx-$ $0.6 \mathrm{eV}$ for the WF difference between ceria NPs and the clean $\mathrm{Cu}(111)$ surface. In comparison with our recent work on ceria/Pt(111) [23], our measurements clearly exemplify that KPFM is measuring the WF of ceria on $\mathrm{Cu}(111)$ and not ceria alone. After a complete oxidation of the surface, the WF difference is close to zero $\left(\triangle \phi_{\mathrm{Ceria} / \mathrm{Cu}-\mathrm{Cu}} \approx-0.1 \ldots 0 \mathrm{eV}\right)$. We speculate that upon oxidation it is ceria, which increases its WF, but also the copper oxide, which slightly decreases its WF. Thanks to KPFM we can assume that there is no strong alloying effect between $\mathrm{Cu}$ and Ce during the reduction unlike the case ceria/Pt(111) [23]: the surface potential is homogeneous and constant on the copper support, only the (111) lattice of $\mathrm{Cu}$ is observed by STM and the ceria NP morphology (NP size and height) does not change upon a redox step unlike on ceria/Pt(111) [23].

\section{Acknowledgements}

Support from the Agence Nationale de la Recherche (ANR) through project REACTIVITY (grant ANR-17-CE09-0045) and CHAMAN (grant ANR-17-CE240011) is gratefully acknowledged. We thank J Falta, J-I Flege, L. Pleines, L Glatthaar, M Reichling and A Soon for stimulating discussions.

\section{ORCID iDs}

A El Barraj https://orcid.org/0000-0002-9947-6935

B Chatelain https://orcid.org/0000-0003-3121-0409

C Barth https://orcid.org/0000-0003-4250-4533

\section{References}

[1] Montini T, Melchionna M, Monai M and Fornasiero P 2016 Chem. Rev. 116 5987-6041

[2] Devaiah D, Reddy L H, Park S E and Reddy B M 2018 Catal. Rev. 60 177-277

[3] Paier J, Penschke C and Sauer J 2013 Chem. Rev. 113 3949-85

[4] Ratnasamy C and Wagner J P 2009 Catal. Rev. 51 325-440

[5] Gorte R J 2010 AIChE J. 56 1126-1135

[6] Fan L, Wang C, Chen M and Zhu B 2013 J. Power Sources 234 154-174

[7] Shaikh S P S, Muchtar A and Somalu M R 2015 Renew. Sustain. Energy Rev. 51 1-8

[8] Fiala R, Figueroba A, Bruix A, Vaclavu M, Rednyk A, Khalakhan I, Vorokhta M, Lavkova J, Illas F, Potin V, Matolinova I, Neyman K M and Matolin V 2016 Appl. Catal. B Environ. $197262-270$

[9] Matsumoto S 2004 Catal. Today 90 183-190

[10] Niu G, Zoellner M H, Schroeder T, Schaefer A, Jhang J H, Zielasek V, Bäumer M, Wilkens H, Wollschläger J, Olbrich R, Lammers C and Reichling M 2015 Phys. Chem. Chem. Phys. 17 $24513-24540$

[11] Freund H J 2010 Chem. Eur. J. $9384-9397$

[12] Luches P and Valeri S 2015 Materials 8 5818-5833

[13] Mullins D R 2015 Surf. Sci. Rep. 70 42-85 
[14] Rodriguez J A, Grinter D C, Liu Z, Palomino R M and Senanayake S D 2017 Chem. Soc. Rev. $461824-1841$

[15] Beran J and Mašek K 2019 Vacuum 167 438-444

[16] Wilson E L, Grau-Crespo R, Pang C L, Cabailh G, Chen Q, Purton J A, Catlow C R A, Brown W A, de Leeuw N H and Thornton G 2008 J. Phys. Chem. C 112 10918-10922

[17] Lu J L, Gao H J, Shaikhutdinov S and Freund H J 2007 Catal. Letters 114 8-16

[18] Luches P, Pagliuca F, Valeri S, Illas F, Preda G and Pacchioni G 2012 J. Phys. Chem. C 116 $1122-1132$

[19] Graciani J, Mudiyanselage K, Xu F, Baber A E, Evans J, Senanayake S D, Stacchiola D J, Liu P, Hrbek J, Sanz J F and Rodriguez J A 2014 Science 345 546-550

[20] Senanayake S D, Ramírez P J, Waluyo I, Kundu S, Mudiyanselage K, Liu Z, Liu Z, Axnanda S, Stacchiola D J, Evans J and Rodriguez J A 2016 J. Phys. Chem. C 120 1778-1784

[21] Rodriguez J A, Graciani J, Evans J, Park J B, Yang F, Stacchiola D, Senanayake S D, Ma S, Pérez M, Liu P, Sanz J F and Hrbek J 2009 Angew. Chemie Int. Ed. 48 8047-8050

[22] Schierbaum K D 1998 Surf. Sci. 399 29-38

[23] Gasperi G, Luches P and Barth C 2018 J. Phys. Chem. C 122 25954-25963

[24] Zhao X, Ma S, Hrbek J and Rodriguez J A 2007 Surf. Sci. 601 2445-2452

[25] Hasegawa T, Shahed S M F, Sainoo Y, Beniya A, Isomura N, Watanabe Y and Komeda T 2014 J. Chem. Phys. 140044711

[26] Yang F, Graciani J, Evans J, Liu P, Hrbek J, Sanz J F and Rodriguez J A 2011 J. Am. Chem. Soc. 133 3444-3451

[27] Mysliveček J, Matolín V and Matolínová I 2015 Materials 8 6346-6359

[28] Siokou A and Nix R M 1999 J. Phys. Chem. B 103 6984-6997

[29] Siokou A and Nix R M 1999 J. Phys. Chem. B 103 6984-6997

[30] Wrobel R, Suchorski Y, Becker S and Weiss H 2008 Surf. Sci. 602 436-442

[31] Šutara F, Cabala M, Sedláček L, Skála T, Škoda M, Matolín V, Prince K C and Cháb V 2008 Thin Solid Films 516 6120-6124

[32] Staudt T, Lykhach Y, Hammer L, Schneider M A, Matolín V and Libuda J 2009 Surf. Sci. 603 3382-3388

[33] Stetsovych V, Pagliuca F, Dvořák F, Duchoň T, Vorokhta M, Aulická M, Lachnitt J, Schernich S, Matolínová I, Veltruská K, Skála T, Mazur D, Mysliveček J, Libuda J and Matolín V 2013 The Journal of Physical Chemistry Letters 4 866-871

[34] Duchon T, Dvořák F, Aulická M, Stetsovych V, Vorokhta M, Mazur D, Veltruská K, Skala T, Myslivecek J, Matolínová I and Matolin V 2013 J. Phys. Chem. C 118 357-365

[35] Hu S, Wang Y, Wang W, Han Y, Fan Q, Feng X, Xu Q and Zhu J 2015 J. Phys. Chem. C 119 3579-3588

[36] Wang Y, Hu S, Xu Q, Ju H and Zhu J 2018 Top. Catal. 61 1227-1236

[37] Tovt A, Stetsovych V, Dvorák F, Johánek V and Mysliveček J 2019 Appl. Surf. Sci. 465 557-563

[38] Mašek K, Beran J and Matolín V 2012 Appl. Surf. Sci. 259 34-38

[39] Höcker J, Duchon T, Veltruská K, Matolín V, Falta J, Senanayake S D and Flege J I 2016 J. Phys. Chem. C 120 4895-4901

[40] Duchoň T, Hackl J, Höcker J, Veltruská K, Matolín V, Falta J, Cramm S, Nemšák S, Schneider C M, Flege J I and Senanayake S D 2017 Ultramicroscopy 183 84-88

[41] Duchon T, Hackl J, Mueller D N, Kullgren J, Du D, Senanayake S D, Mouls C, Gottlob D M, Khan M I, Cramm S, Veltruská K, Matolín V, Nemšák S and Schneider C M 2020 J. Mater. Chem. A 8 5501-5507

[42] Škoda M, Cabala M, Matolínová I, Skála T, Veltruská K and Matolín V 2010 Vacuum 84 8-12

[43] Happel M, Lykhach Y, Tsud N, Skála T, Prince K C, Matolín V and Libuda J 2011 J. Phys. Chem. C 115 19872-19882

[44] Chen B, Ma Y, Ding L, Xu L, Wu Z, Yuan Q and Huang W 2013 J. Phys. Chem. C 117 $5800-5810$

[45] Hu S, Wang W, Wang Y, Xu Q and Zhu J 2015 J. Phys. Chem. C 119 18257-18266

[46] Wang W J, Wang Y, Xu Q, Ju H X, Wang T, Tao Z J, Hu S W and Zhu J F 2017 Chinese Chem. Lett. 28 1760-1766

[47] Wang Y, Li X, Hu S, Xu Q, Ju H and Zhu J 2018 Acta Physico-Chimica Sin. 34 1381-1389

[48] Lykhach Y, Skála T, Neitzel A, Tsud N, Beranová K, Prince K C, Matolín V and Libuda J 2020 Chinese J. Catal. 41 985-997

[49] Szabová L, Stetsovych O, Dvořák F, Farnesi Camellone M, Fabris S, Mysliveček J and Matolín V 2012 J. Phys. Chem. C 116 6677-6684

[50] Graciani J, Vidal A B, Rodriguez J A and Sanz J F 2014 J. Phys. Chem. C 118 26931-26938

[51] Yang B X, Luo Y and Ye L P 2018 J. Mol. Model. 2420 
[52] Luches P, Pagliuca F and Valeri S 2014 Phys. Chem. Chem. Phys. 16 18848-18857

[53] Barth C, Claeys C and Henry C R 2005 Rev. Sci. Instr. 76083907

[54] Kitamura S, Suzuki K and Iwatsuki M 1999 Appl. Surf. Sci. 140 265-270

[55] Barth C, Hynninen T, Bieletzki M, Henry C R, Foster A S, Esch F and Heiz U 2010 New J. Phys. 12093024

[56] Jensen F, Besenbacher F and Stensgaard I 1992 Surf. Sci. 269-270 400-404

[57] Matsumoto T, Bennett R, Stone P, Yamada T, Domen K and Bowker M 2001 Surf. Sci. 471 $225-245$

[58] Yang F, Choi Y, Liu P, Hrbek J and Rodriguez J A 2010 J. Phys. Chem. C 114 17042-17050

[59] Lee Y J, Ly T T, Lee T, Palotás K, Jeong S Y, Kim J and Soon A 2021 Appl. Surf. Sci. 562 150148

[60] Wiame F, Maurice V and Marcus P 2007 Surf. Sci. 601 1193-1204

[61] Therrien A J, Zhang R, Lucci F R, Marcinkowski M D, Hensley A, McEwen J S and Sykes E C H 2016 J. Phys. Chem. C 120 10879-10886

[62] Judd R W, Hollins P and Pritchard J 1986 Surf. Sci. 171 643-653

[63] Höcker J, Cartas W, Schaefer A, Bäumer M, Weaver J F, Falta J and Flege J I 2015 J. Phys. Chem. C 119 14175-14184

[64] Waluyo I, Mudiyanselage K, Xu F, An W, Liu P, Boscoboinik J A, Rodriguez J A and Stacchiola D J 2019 J. Phys. Chem. C 123 8057-8066

[65] Matencio S, Barrena E and Ocal C 2016 Phys. Chem. Chem. Phys. 18 33303-33309

[66] Barth C, Laffon C, Olbrich R, Ranguis A, Parent P and Reichling M 2016 Sci. Rep. 621165

[67] Olbrich R, Pieper H H, Oelke R, Wilkens H, Wollschläger J, Zoellner M H, Schroeder T and Reichling M 2014 Appl. Phys. Lett. 104081910

[68] Pieper H H, Barth C and Reichling M 2012 Appl. Phys. Lett. 101051601

[69] Wilkens H, Schuckmann O, Oelke R, Gevers S, Reichling M, Schaefer A, Bäumer M, Zoellner M H, Niu G, Schroeder T and Wollschläger J 2013 Phys. Chem. Chem. Phys. 15 18589-18599

[70] Pleines L, Buß L, Mentes T O, Genuzio F, Locatelli A, Falta J and Flege J I 2021 For submission to: J. Phys: Condens. Matter.

[71] Grönbeck H and Barth C 2019 J. Phys. Chem. C 123 24615-24625

[72] Palacios-Lidon E, Henry C R and Barth C 2014 ACS Catal. 4 1838-1844

[73] Chiter F, Costa D, Maurice V and Marcus P 2020 J. Phys. Chem. C 124 17048-17057 